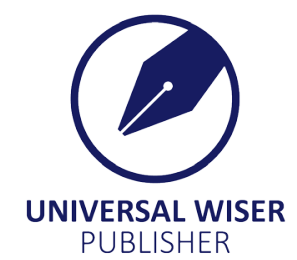

\title{
Basic Exposition of National Political Economy
}

\author{
Yang Xinluo*, He Zongshu \\ Xichang University, Liangshan Yi Autonomous Prefecture, Sichuan Province, China \\ Email:1461324812@qq.com
}

\begin{abstract}
Since Adam Smith published his book The Wealth of Nations in 1776, it marked the birth of political economics and represented the beginning of all the studies of political economics. But when Adam Smith's ideas were really applied to reality, many problems arose, such as the overflow of social Darwinism and the outbreak of the economic crisis. On this basis, the author puts forward "national political economy", expecting to solve a series of problems that have occurred and may occur through "national political economy" and its ideas, and ultimately improve the current economic system and political system. This article mainly has a basic exposition of "national political economy", and puts forward the policy to solve the current problems.
\end{abstract}

Keywords: political economy, political philosophy, economic philosophy, national political economy

\section{The background of "national political economy"}

Political economics is a discipline that studies economic activities, economic relations and economic laws such as social production, capital, circulation, exchange, distribution and consumption. Adam Smith believes that it is a science that studies the generation and distribution of national wealth. However, no matter what people think of it, it is the foundation of modern democratic political system. All the spiritual and material wealth of modern society are closely related to political economy. The basis of political economy is market economy, while market economy is based on selfinterest ${ }^{[1]}$. The so-called self-interest is an egoistic human exchange tendency based on personal interests. The self-interest behavior of human beings is the process of pursuing their own interests. Adam Smith believes that due to the guidance and regulation of the "invisible hand", economic man pursues the maximization of his own interests while also promoting the growth of social and public interests. When self-interest accumulates to a certain amount, altruism will appear, and selfinterest and altruism will gradually form mutual benefit in the process of market competition ${ }^{[1]}$. In a word, Adam Smith believes that respecting self-interest, recognizing other interests, and developing mutual benefits constitute the basis of the development principles of economics and political economics ${ }^{[2]}$.

But just because all political economics attaches too much importance to self-interest, it only recognizes other interests, and it only adds to each other's benefits ${ }^{[3]}$. In fact, mutual benefit is the ultimate choice of individuals who adhere to the principle of self-interest ${ }^{[4]}$. Mutual benefit is still self-interest in essence ${ }^{[5]}$. This makes the emphasis on the state and the nation far from enough, because its fundamental lies in the self-interest of people rather than the moral level, it does not achieve the balance between the two as the Ecclesiastes said ${ }^{[6]}$, "so that I am not poor, nor rich, give me the food I need. I am afraid I will not recognize you when I am full and say who is the Lord? Or lest I be poor and steal, so as to profane the name of my $\operatorname{God}^{[7]}$." In fact, Adam Smith has realized that self-interest and self-interest may make mistakes ${ }^{[8]}$, but he believes that such problems can be solved by the inevitable development of altruism and mutual benefit ${ }^{[9]}$. "Although the pursuit of personal interests, but because of the role of the market economy"natural order ${ }^{[10] \text { ', }}$, will inevitably lead to universal social welfare ${ }^{[11]}$." Although this idea is extremely beautiful and perfect ${ }^{[12]}$, the facts from the later stage of the first industrial revolution and the second industrial revolution are not as beautiful as Adam Smith described ${ }^{[13]}$. Capitalists' greed for capital profits not only did not make him suffer God's punishment, let him know that "greed" is one of the seven sins; instead, they intensified their costs, crushing workers wantonly ${ }^{[14]}$, expecting to squeeze the last drop of blood from them ${ }^{[15]}$. Such serious and inhumane exploitation caused workers to demonstrate and resist one after another ${ }^{[16]}$. But the author believes that neither capitalists nor exploited workers ${ }^{[17]}$, represented by workers, want such fierce conflicts ${ }^{[18]}$. In the final analysis, all these are political and economic systems are not perfect enough ${ }^{[19]}$.

On this basis, there have been many economic crises, whether capitalists or laborers, as well as the national

Copyright (C2020, Yang Xinluo, et al.

DOI: https://doi.org/10.37256/ges.122020120

This is an open-access article distributed under a CC BY license

(Creative Commons Attribution 4.0 International License)

https://creativecommons.org/licenses/by/4.0/ 
government can not stand the continuous emergence of such a cycle of crises over the years, many of them smart people put forward a lot of seemingly effective policies ${ }^{[20]}$, such as Keynesianism and monetarism, but unfortunately ${ }^{[21]}$, after the test of practice, these doctrines can not be fundamentally understood. The decisive question ${ }^{[2]}$, because they all attach too much importance to self-interest and self-interest, and forget the great stone pillars of the Parthenon Temple engraved on the sage of Socrates, "Man! Know yourself. ${ }^{[23], "}$ As human beings, we not only have the natural right to be human, but also have moral obligations that can not be chosen by us, such as the duty of loyalty to the country and nation of birth, compassion for the same kind and so ${ }^{[24]}$. Although there are always many people who say that these are not their own choices can not be counted as their obligations. But I also want to say that whether God appoints you to be human or Buddhism says that fate makes you human, since you intend to enjoy the natural right to be human, then you should fulfill the moral obligation of being human, which is equal and unconditional. In this context, the author puts forward the "national political economy ${ }^{,[25]}$, which will try to make the economic policy and political system conform to the national conditions of various countries through the regulation and control of the national government and national environment, and to some extent inhibit the outbreak of social Darwinism and economic crisis ${ }^{[26]}$.

\section{Definition of "national political economy"}

"National political economy" means that while respecting the order of the market itself, the market economy is regulated to a certain extent through the strength of the national government ${ }^{[28]}$. Such regulation can not be too excessive, but it can not be completely absent. Through such regulation, the middle and lower class people and workers in our country can obtain the maximum benefits, and the interests of capitalists are the same. They will not be treated too inhumanely. The national government's status in the market economy is a regulator, and it can't and can't directly participate in the competition of the market economy ${ }^{[28]}$, because when the national government can participate in the competition of the market economy, it will inevitably bring about absolute corruption and covert operation ${ }^{[29]}$, which is contrary to the legal spirit of any country, which is also contrary to the natural rights we were born with. It is fundamentally contrary ${ }^{[30]}$.

Simply put, "national political economy" is to ensure the majority of the legitimate interests of the upper class, through the legal means of the state and various controls ${ }^{[31]}$, to maximize the willingness to work hard to enable the lower and middle-class people to live a rich and happy life. Fundamentally speaking, under the condition of guaranteeing absolute respect for individual's natural rights ${ }^{[32]}$, national government plays its political role, moral enlightenment plays its ideological role $\mathrm{e}^{[33]}$, maximizes the happiness of mankind as much as possible and fulfills our inherent moral obligations, resists the negative effects and functions brought about by social Darwinism, and minimizes the classics. The adverse effects of the economic crisis on all countries in the world ${ }^{[34]}$.

\section{Extension of "national political economy"}

"National political economy" not only represents the growth of economic interests through the regulation of political means of the national government ${ }^{[2]}$, but also represents the change from the ideological and moral level. The current "political economy" is not a pure political economy, it has an economic role and political impact, but the author believes that it ignores the moral level of education ${ }^{[2]}$. We should vaguely remember that in the Analects, when Confucius answered the questions of national economy, national politics and people's livelihood management, there were only a few words ${ }^{[2]}$ : "Make them obedient, make them rich, and make them wise". However, the traditional political economy does not think $\mathrm{so}^{[2]}$. From The Wealth of Nations, we can see that the assumption of the traditional political economy on economic individuals is individualism ${ }^{[35]}$. Individualists believe that both the theory of natural human rights and the theory of human selfishness are correct ${ }^{[36]}$, so they assume that human beings do have the power to be good ${ }^{[37]}$, but at the same time they are convinced that human beings have insurmountable selfishness ${ }^{[38]}$. If such assumptions are more objective and fair, the remaining assumptions are inequitable, and individualists have a natural distrust of any government. On the other hand, Adam Smith, the founder of political economics and economics, believed that the citizen government had experienced six stages: hunting stage, animal husbandry stage, the early stage of agriculture, the middle stage of agriculture stage: city-state stage, the late stage of agriculture: feudal stage, commercial stage. Adam Smith believed that the real government could not be formed in the hunting stage because the economy was very simple and the property was very few, so people did not need to depend on others economically; but in the livestock stage, the private ownership of cattle and sheep, which caused uneven wealth, was the reason for the real government. In order to establish the authority to protect property rights, it is necessary to establish a government and a fair law, but such a statement is unfair, because if we go back to the situation at that time, we will find that the original and final purpose of the government is to maintain social stability and the 
management of the people, and to safeguard the private rights of the rich is not the fundamental purpose of the government, if we go back to the situation at that time. With the fundamental purpose of safeguarding the private rights of the rich, it is impossible for a government to consolidate its own rule. It cannot consolidate its own rule. It can only be replaced by a more advanced, wiser and competitive government of the times. To give a well-known example, in the Yuan Dynasty of China, when the Mongolian raced around the world, Genghis Khan established Mongolia. The ancient empire spanned the Eurasian continent, but because it did not realize the drawbacks of its political system and government, after Genghis Khan's death, the Mongolian Empire quickly decomposed. In China led by Kublai Khan, the first class was Mongolian, the second class was colourful and the third class was Han (Han people here do not represent Han people). The Han people, also not the Chinese, mean the Han and Qidan and Nuchen nationalities in the original Jin Dynasty north of the Huaihe River $^{[39]}$. The fourth class is from the South (the southern people here include the vast majority of the present Chinese, referring to all the people in the former Southern Song Dynasty who were conquered by the Yuan Dynasty). Under such a four-class system, the Yuan government was private to the first two classes, especially the Mongolians. Because of the great protection of rights, other people in its territory were dissatisfied, so the Yuan Dynasty, the strongest Mongolian empire across Eurasia, quickly perished after less than 100 years of government rule. Zhu Yuanzhang, the founder of the Ming Dynasty ${ }^{[40]}$, replaced it with the Ming Dynasty. From this historical fact, we can know that if any system can not give justice to the vast majority of the people, then the government will be very easy to perish; similarly, if the purpose of creating the government is to protect the private rights of some nobles or rich people ${ }^{[41]}$, and can not give enough justice to the people, then such a government will inevitably be overthrown by the broad masses ${ }^{[42]}$, which is not true. Only in China, there are many examples in Europe, such as the British bourgeois revolution and the French Revolution triggered by the enclosure movement. All governments must apply to the social environment at that time. Otherwise, they will be eliminated ${ }^{[43]}$.

Therefore, on this basis, we find that if the government is not as unreliable as Adam Smith said, then the traditional political economy needs to reflect on whether it should be modified to a certain extent in order to better adapt to today's society $^{[44]}$. If we admit that the national government is not so unreliable, then we should regulate all economic activities to a certain extent through the means of national regulation, so that all economic activities must be controllable and beneficial to the country ${ }^{[45]}$.

Implementing "national political economy" and recognizing the status of the national government, and since it is impossible for the organization of the national government to commit treason collectively, it is necessary to support the organization of the national government from another angle, that is, to fulfill our moral obligations. As mentioned earlier, we are born with moral obligations, such as the duty of loyalty to the country of birth, the nation ${ }^{[46]}$, compassion for the same kind, and so on. These are our inescapable responsibilities and obligations. Chinese Confucianism once said very well that "poor people are good for themselves and help the world at the same time ${ }^{[47]}$." Whether they are middle or lower class people or upper class people, they should fulfill such obligations in accordance with their own personal conditions ${ }^{[48]}$. We have always been convinced that human beings are not a complete animal. We do have a natural animal nature ${ }^{[49]}$. We have to eat other animals' corpses or plants to maintain our physiological needs. In this respect, we are no different from animals. But similarly, we are not a complete animal. We know how to think, how to analyze ourselves and how to reflect on ourselves. Self-improvement, self-development, our spirit is flowing with the light of divinity, our consciousness retains the last hope in Pandora's box. We should shoulder the responsibility of being born as human beings, fulfill the obligation of being born as human beings, and enjoy the natural rights of being born as human beings. Through "National Political Economics", I hope that more people will understand that they are closely connected with the state and the nation. Economics and political economics are no longer just a bunch of cold numbers and symbols, not just unfamiliar nouns and formulas, but also contain the spirit of great divinity and humanism.

Our academic research needs to serve the country and the world. The concept of the world is too nihilistic. Once we mention the concept of "collective" for thousands of years, we think of the state and the nation, not the very nihilistic concept of cosmopolitanism. Our research on "national political economy" comes from our urgent hope for national prosperity. The theme of today's world should not be "peace and development", but still diplomacy and competition. Diplomacy is the extension of internal affairs. Only paying attention to diplomacy is bound to become the doll and tool of great powers. Once the internal affairs are clear, the national strength will inevitably rise, which makes the big countries dare not ignore their own power at will ${ }^{[50]}$. If we want to achieve a clear and clear internal affairs, we must make the people rich and strong, and the state's macro-control policy must meet this goal. Therefore, "national political economy" is very important ${ }^{[51]}$.

Adam Smith's theory of international division of labor and market liberalism has a great influence in the world. Many 
economists engaged in economic reform are faithful believers of Adam Smith School. However, I think that economics should not be pure economics that studies the general interests of mankind, but the "nationalism" economics that focuses on the economic interests of the nation and state ${ }^{[52]}$. If it is carried out according to Adam Smith's theory of international division of labor, the backward countries should not develop their own national industries, but should only give full play to the natural endowment to provide wood, coal and rough products for advanced countries. Liszt once pointed out that Adam Smith's idea is not a theory, but a kind of world policy or strategy of Britain. Its purpose is to make the backward countries unable to develop and can only serve as a foil for the advanced countries ${ }^{[53]}$. We need to make it clear that the purpose of developing market economy should be to cultivate and strengthen China's industrial productivity and export competitiveness, rather than destroy and contain the development of domestic economic productivity.

\section{The policy conception of "national political economics"}

As mentioned above, the focus of "national political economy" is to achieve steady economic growth and social stability through a certain degree of state regulation and control means. So the most fundamental problem is how to achieve such a certain degree of regulation and control? Or what criteria should be adopted to quantify such regulation? In my opinion, this standard lies in the people themselves. As mentioned above, the initial and final purpose of the national government is to maintain social stability, and the fundamental purpose of the government is to safeguard the interests of the majority. We can't become democratic violence like the Athens polis in ancient Greece. Confucius said that "the people can let them do, can't let them know." That's why the people need the government to make a reasonable judgment for them. But similarly, the reason why the people are willing to give power to the government is that the government must give a reasonable solution for the majority of people. Just as the citizens go to the Gold shop to book a gold necklace, the citizens pay most of their money in advance ${ }^{[54]}$, so the Gold shop must give the citizens a corresponding gold necklace, otherwise such a transaction will be difficult to sustain, the citizens will inevitably choose other gold shops next time or establish another new one after the collapse of such gold shops, so will the relationship between the government and the people. It is impossible to concentrate power in the hands of individuals or individual families as feudal autocratic rule did, because such relations are prone to various problems, and it is difficult to achieve the purpose of safeguarding the interests of the majority ${ }^{[5]}$.

So since we can't put the balance in the hands of individuals or small groups (family is also a small group), then I think we can only put the balance in the hands of the people. I Ching, the first of China's classics, once said that ,"If we can understand the truth of the people in the world, we will achieve immortal fame and position." Chuang Tzu also said, "It seems very reliable to hide the boat in the mountain ditch and fishing gear in the deep water. But if an angel carries them on his back with the valleys and rivers in the middle of the night, the sleeping people don't know at all. It is appropriate to hide small things in big things, but they will still be lost. If we hide the world in the sky without losing it, this is the inherent truth of things. In this way, we can find that it is most appropriate to give the standard to the people. Su Shi, a poet of the Song Dynasty, said in his poem, "When spring comes, the river is warmer, and ducks must know it first.", which means that only the people in the upper, middle and lower classes of society know what the people really need and what kind of problems they have. All the government needs to do is to clarify the problem and give the corresponding control plan and suggestions to the people at all levels ${ }^{[56]}$.

But handing over standards to the people does not mean supporting democratic violence. The reasons for the demise of Athenian polis in ancient Greece and the death of the sage Socrates are still hanging over everyone's head like the sword of Damocles. It reminds us that we can't excessively hand over power to unsuitable people. Everyone is born with natural rights. He is also in this country and society. We have the right to ask questions and make suggestions, just like when we go to a restaurant to eat. Since the guests spend money, even though they may not be able to cook a dish, the guests can still make their own comments and suggestions on the dish. The national government is equivalent to a restaurant, the guests are equivalent to the people, the administrative officials are equivalent to the cook, and each dish is equivalent to a restaurant. All dishes are laws and policies promulgated by the state. The so-called spending is the amount of tax paid by the people to the state. So people have a natural right to ask questions and give suggestions about the politics of the country, which need not be argued. But this is not a legitimate reason or a legitimate excuse for some ulterior ambitious people to steal power, nor does it mean that people need to use power themselves. Lao Tzu, a philosopher in the pre-Qin period of ancient China, once said, "The sharp weapon of the country (it means the power of the state) can not be shown to others", and Confucius also said, "the people can let them do, can't let them know." All these show that Lao Tzu and Confucius have a mature view of national policy. The country can be a people's country, but the people can not form democratic violence, counter-attack the country's intellectuals, or even disturb the state's politics. 
So in order to neither form democratic violence nor concentrate power in the hands of individual people, we should implement the corresponding system. First, the power center of the country should be chosen directly or indirectly by the people, who represent the highest wisdom of the country (wisdom here not only represents scientific and technological wisdom, but also attaches more importance to human wisdom in governing the country); secondly, the government should meet the representatives selected by various strata once a quarter, and they should not be too many or too few, and too much will waste the future execution of government. If the policy time is too short, it will not necessarily be able to hear enough useful information, listen to their opinions, communicate face to face with them, synthesize the problems and opinions put forward by various representatives and strata, discuss them by the national power center, and finally give the corresponding solutions and promulgate the corresponding policies and regulations. Thirdly, the policy formulation of the national government should respect the policies of all strata. Opinions should not only pay attention to the opinions of the upper class, but also to the opinions of the lower and middle class. Li Shi min, Taizong of Tang Dynasty in ancient China, said, "At the same time, only by listening to the opinions of all parties can we correctly understand things; if we only believe in one-sided words, we will inevitably make one-sided mistakes." All strata should be discussed comprehensively. Finally, under the condition of ensuring that the basic interests of all strata are not harmed, incentive policies for the lower and middle class people should be given to the upper class so as to encourage economic development and politics. Fourthly, the laws of the national government must be sacred and inviolable, and the laws need to prohibit all activities that incite disturbances or incite harmonious and stable relations among the people of all strata for any purpose. The planners and implementers of these activities must be punished severely. The government needs to set up a transit agency, which is not for commercial profit. It is responsible for receiving letters from all walks of life asking questions and proposing suggestions, and submitting letters of higher quality to the national government as appropriate. Sixth, for the writers of letters of higher quality, the national government should introduce them into the national government as appropriate to make suggestions for the development of the country. At the same time, we should avoid the outflow of excellent talent resources; seventhly, the national government should attach great importance to ideological education, to ensure that when the national government is out of balance, the people themselves can still avoid confusion and ruthlessness, so that contradictions among all strata will not evolve to an irreconcilable level, and the economy has been in steady development; eighth, all legal policies must develop economy and humanities. Emphasis should be laid on both sides. Natural ecology, social ecology and moral ecology should be guaranteed to be in good condition. At the same time, the economy should strive for steady progress ${ }^{[57]}$.

Some of the above policy concepts about the implementation of "national political economy" conceived by the author may not be perfect, and some policies may be too empty. After all, national policies are difficult to talk about on paper, and some changes and adjustments must be made in actual operation. Therefore, it is impossible to say too detailed and forgiving.

\section{Concluding remarks}

The basic exposition of "national political economy" has been finished, and the remaining theoretical theory of "national political economy" can not be continued in a paper. The author puts forward that "national political economy" is to make peace between countries more lasting, also for the harmonious and stable relations among various classes within countries, and also for the sake of making the whole human race no longer just a group of selfish and ruthless animals, we are born as human beings, and we must fulfill our obligations when we have rights. For the first time, Attila, the Hun King, was called "the whip of God", and for the second time Genghis Khan, who was called "the whip of God", the author believes that the third "the whip of God" should be addressed to human selfishness and the resulting social Darwinism and economic crisis. In order to overcome such a crisis, the author believes that there is no way but to use the theory of "national political economy" as the representative, which emphasizes moral obligation and humanistic concern.

\section{Reference}

[1] Adam Smith. The Wealth of Nations. South China Sea Publishing Company; 2012.

[2] Whiteside Heather. Canadian Political Economy. University of Toronto Publishing; 2020.

[3] Guo Guanqing. Political economy analysis of agricultural and rural modernization in New China. Economic and Management Review. 2020; 5: 14-26. Available from: https://doi.org/10.13962/j.cnki.37-1486/f.2020.05.002.

[4] Zhao Jianjian. Research on Marx's thought of human nature from the perspective of broad spectrum Philosophy. Dialectics of Nature. 2020; 36(09): 124-128. 
[5] Gu Hailiang. Theoretical sublimation of socialist political economy with Chinese characteristics in the new development stage. Economic Daily. 2020.

[6] Fang Rui. The interpretation path and theoretical difficulties of capital method. Zhejiang Social Sciences. 2020; 9: 105-111, 160.

[7] He Xin. Reform and strategy. 2020; 36(09): 2, 125.

[8] Niu Xinxing. The four dimensions of Marx's labor theory and its implication. Reform and Strategy. 2020; 36(09): 1320.

[9] Wang Hua, Jiang Fuyou. Economic Research on Rural Revitalization in the new era. Modern Agriculture. 2020; 9: 53-55.

[10] Yang Mingxing. Poverty Alleviation: the vivid practice of socialist political economy with Chinese characteristics. Hunan Daily. 2020.

[11] Ding Yu. Answering questions of the times and promoting theoretical innovation. China Journal of Discipline Inspection and Supervision. 2020.

[12] Sujit Kumar Mishra, R Siva Prasad. Displacement, Impoverishment and Exclusion: Political Economy of Development in India. ThriftBooks; 2020.

[13] Fang Jian. Research on the distribution system of value-added income from collective land expropriation: Current situation and future. Learning Forum. 2020; 9: 52-60.

[14] Li Xudong. Livelihood and rational action logic of alternative farming: the cultural practice process of vegetable farmers in Beijing suburbs. Beijing Social Sciences. 2020; 9: 4-12.

[15] Li Yiping. Enriching and developing socialist political economy with Chinese characteristics in vivid practice. Economic Daily. 2020.

[16] Leila Simona Talani. European Political Economy: Issues and Theories. Taylor and Francis; 2014.

[17] Paul Mattick Jr. Economic Crisis and Crisis Theory. Taylor and Francis; 1974.

[18] Lena Rethel. The Political Economy of Financial Development in Malaysia: From the Asian Crisis to 1MDB. Taylor and Francis; 2020.

[19] Beniamino Callegari. Foundations of Post-Schumpeterian Economics: Innovation, Institutions and Finance. Taylor and Francis; 2020.

[20] Elina Kuorelahti. The Political Economy of International Commodity Cartels: An Economic History of the European Timber Trade in the 1930s. Taylor and Francis; 2020.

[21] Jørgen Pedersen. Distributive Justice and Taxation. Taylor and Francis; 2020.

[22] Li Xuesong. Methodology of scientific application of Marxist Political Economy. Hubei Daily. 2020.

[23] Xu Yuelei. Political economy analysis of the concept of "scientific and technological innovation". Shenyang municipal Party committee and Shenyang Municipal People's government. Proceedings of the 17th Shenyang Annual Conference on science and technology. Shenyang municipal Party committee and Shenyang Municipal People's Government: Shenyang Association of Science and technology. 2020.

[24] Essence of Party journals. Party life in Qinghai. 2020; 9: 19.

[25] Zhang Jiayuan. Marxist analysis and criticism on Ecological capitalism and carbon trading. Shanxi Youth. 2020; 18: 11-13.

[26] Tian Jiangtai. Community of human destiny: the creation of a new global civilization-Based on the perspective of political economy. Journal of China University of mining and Technology. 2020. Available from: http://kns.cnki.net/ $\mathrm{kcms} /$ detail/32.1593.C.20200907.1112.002.html.

[27] Hu Yuemin, Hu Huixin, Wu Wei. A probe into Marx's surpassing classical political economy-from the perspective of economic crisis. Journal of Northwestern University (Philosophy and Social Sciences). 2020; 50(05): 37-46.

[28] Li Peng. Upholding and developing Marxist political economy in contemporary China. China Party and Government Cadres Forum. 2020; 9: 44-47.

[29] Xi Jinping: Focus on the long-term trend and grasp the general trend of the policy benefit by mutual discussion and new research plan (full text of the speech). Economic Management Digest. 2020; 17: 3-6.

[30] Fu Wenjun. Marx's historical understanding and substantive criticism of capital category-Based on the investigation of economic manuscripts of 1857-1858. Nanjing Social Sciences. 2020; 8: 46-51.

[31] Hong Yinxing. Socialist political economy with Chinese characteristics entering a new era. Management world. 2020; 36(09): 1-11.

[32] Jin Bei. On the paradigm commitment of socialist economics with Chinese characteristics. Management world. 2020; 36(09): 11-18, 53.

[33] Fang Fuqian. Several important theoretical issues of borrowing western economics in the new era. Management World. 2020; 36(09): 18-26.

[34] Chen Shihua. Trapped by "Yan": Criticism of political economy of communication with face changing. Nanjing 
Social Sciences. 2020; 8: 100-109.

[35] Giorel Curran. Divestment, energy incumbency and the global political economy of energy transition: the case of Adani’s Carmichael mine in Australia. Climate Policy. 2020; 20(8).

[36] Yu Weiru. The rise of "flow society" and its political economy analysis. Theory and reform. 2020; 5: 177-188.

[37] Li Zhi. Practical philosophical interpretation of Marx's theoretical criticism. Journal of Wuhan University (Philosophy and Social Sciences). 2020; 73(05): 25-35.

[38] Eric M. P. Chiu, Thomas D. Willett. Capital Controls and Currency Crises Revisited: A Political Economy Analysis. Emerging Markets Finance and Trade. 2020; 56(12).

[39] Economics-Political Economics. New political economics findings has been reported by investigators at university of Toronto (sharp bounds and testability of a roy model of stem major choices). Politics \& Government Business. 2020.

[40] Economics-Political Economics. Investigators at university of pennsylvania discuss findings in political economics (on the identification of gross output production functions). Politics \& Government Business. 2020.

[41] Economics-Political Economics. Findings on political economics reported by investigators at university of Lisbon (Fiscal discipline and exchange rates: Does politics matter?). Politics \& Government Week. 2020.

[42] Economics-Political Economics. New findings on political economics described by investigators at Northwestern University (The strategy and technology of conflict). Politics \& Government Week. 2020.

[43] Economics-Political Economics. New findings from university of Arkansas describe advances in political economics (Improving college instruction through incentives). Politics \& Government Week. 2020.

[44] Teklie Tesfamariam Berhe. Political economy of rent seeking in local governance: Causes, forms, and responses towards (Evidences from Adigrat town administration, Ethiopia). Journal of Public Policy and Administration. 2020; $4(3)$.

[45] Zheng Jianxiong, Fang Xingxing. Global industrial chain reconstruction and China's response under the influence of the new epidemic. Journal of South China Normal University (Social Science). 2020. Available from: http://kns.cnki. net/kcms/detail/44.1139.C.20200901.1602.002.html.

[46] Xue Jiaqi, Wu Hao. Research on the contribution of national economic critical outline to Marxist Political EconomyCommemorating the 200th anniversary of Engels' birth. Journal of Hebei University of Economics and Trade. 2020. Available from: https://doi.org/10.14178/j.cnki.issn1007-2101.20200831.003.

[47] Zhou Wen, Dai Hongdou. An analysis of the research object of socialist political economy with Chinese characteristics: contemporary reference based on Marx's production mode theory. Journal of Hebei University of economic and Trade. 2020. Available from: https://doi.org/10.14178/j.cnki.issn1007-2101.20200831.002.

[48] Learning time. Economics. 2020; 9: 6-15.

[49] Lin Luhang. Song Tao's contribution to the development of socialist economic theory. Southeast Academic Journal. 2020; 5: 69-76.

[50] China's magazine "seeking truth" published an important article by general secretary Xi Jinping, “constantly developing the new realm of contemporary Chinese Marx's political economics". Wll-Off. 2020; 25: 20.

[51] Firmly grasp the scientific guide of China's economic development. Xiaokang. 2020; 25: 21.

[52] Is seeking to publish the important article of general secretary Xi Jinping, "constantly developing new realms of Marx's political economics in contemporary China". China Radio and TV Journal. 2020; 9: 1.

[53] Fang Xi. Theoretical evolution and practical innovation of China’s ownership. Social Science Front. 2020 ; 9: 56-65.

[54] Jiang yongmu, Wan Teng, Lu Yang. Political and economic analysis of China's elimination of absolute poverty-Based on Marxist theory of institutional poverty reduction. Social Science Front. 2020; 9: 167-176.

[55] Xi Jinping. Speech at the Symposium of experts in the economic and social field. Communist Party Member (Hebei). 2020; 17: 1, 4-6.

[56] Ding Guoqiang. Scientific application of the basic principles and methodology of Marxist Political Economy. China Journal of Discipline Inspection and Supervision. 2020.

[57] Our commentator. Improving the ability and level of leading China's economic development. People's Daily. 2020. 